\title{
Oil and Gas: a Blessing for Few. Hydrocarbons and Inequality Within Regions
}

\author{
in Russia \\ TULLIO BUCCELLATO AND TOMASZ MICKIEWICZ
}

(forthcoming in "Europe-Asia Studies", 2009)

\begin{abstract}
Building on earlier work on regional inequality in Russia the article seeks to demonstrate that the regional oil and gas abundance is associated with high within-region inequality. It provides empirical evidence that hydrocarbons represent one of the leading determinants of an increased gap between rich and poor in the producing regions. The discussion focuses on a possible cluster of geographic, economic and political factors underlying the phenomenon.
\end{abstract}

SINCE 1999, GROWTH IN RUSSIAN GDP HAS BEEN ACCOMPANIED BY CONTINUED high levels of inequality. ${ }^{1}$ Russia is now characterised by more dramatic social differences than most of the other transition economies. The inequality has stabilised at a level comparable to some countries in Latin America, like Venezuela, in Africa, like Nigeria and in the Middle East, like Iran (all net oil exporters). Among possible causal factors, revenues from hydrocarbons seem to have played an important role in affecting the heterogeneity of incomes across the population. Oil and gas, as with other natural resources, represent an easily appropriable and excludable source of wealth. The privileged, who have gained access to oil and gas revenues, have enjoyed a disproportionate increase in their living standards, enlarging the gap with the rest of the population.

In this article, we investigate the hypothesis that growth led by natural resources could be associated not only with the widening in differences of living standards across Russian regions but also within regions. In particular, we demonstrate that regions rich in oil are characterised by a higher level of income inequality. We also discuss possible geographic, economic and political explanations for this phenomenon. We argue that some theoretical intuitions drawn from cross-country comparisons may also apply to the cross-regional comparisons, given the geographical, economic and social diversity and the federal character of Russia. ${ }^{2}$ In particular, some of the theoretical explanations linking the

\footnotetext{
We would like to express our gratitude to Michael Bradshaw, Peter Duncan, Bassam Fattouh, Christine Fernandes, Christopher Gerry, Carol Leonard, Pasquale Scaramozzino, Paul Segal, Laixiang Sun, Victor Winston and the seminar participants at the Oxford Institute of Energy Studies, University of Oxford, and the School of Oriental and African Studies, University of London for valuable comments and criticism. All remaining errors are ours.

${ }^{1}$ Over the period 2000-2006 the income-based Gini index had remained at the level of 0.40-0.41 (Source: Goskomstat, Statistical Yearbook of Russia, 2006). See also Svedberg et al. (2006).

${ }^{2}$ Popov (2001) makes a similar argument.
} 
presence of subsoil hydrocarbons with differences in within-country inequality may also apply to differences in withinregion inequality.

In the economic literature, the role of oil, gas, and - more generally — of natural resources has been broadly discussed as having an ambiguous impact on economic prosperity, development and long-run growth (Corden \& Neary 1982; Eastwood \& Venables 1982; Corden 1984; Sachs \& Warner 2001; Davis \& Tilton 2005). While, positive effects of natural resource endowment on growth are likely (Sala-i-Martin et al. 2004), this may not always be the case, and more importantly the gains from growth may not be equally shared. There are several factors that may induce the latter phenomenon. Boom in the hydrocarbons sector may affect other sectors negatively, including the shift of investments towards traded natural resources and non-tradable sectors preventing diversified economic growth. ${ }^{3}$ High concentration of rents in the hydrocarbons sector, where not accompanied by efficient institutions and government policy, may result in a skewed distribution of income (Davis \& Tilton 2005). In addition, natural resource abundance may stimulate rentseeking behaviour that, together with highly concentrated bureaucratic power, induces corruption in the economy and hence, lowers the quality of institutions (Leite \& Weidmann 1999; Davis \& Tilton 2005). The latter may enhance income inequality via its negative effect on entrepreneurial entry (Gylfason \& Zoega 2002). This strand of the literature demonstrates that focus on the link between natural resource endowment and inequality is important not only because the question itself matters, but also because inequality may have implications for other aspects of economic development, including poverty. ${ }^{4}$

In this article we are interested to which degree some of these country-level phenomena are applicable to the regions of Russia. We focus on the local effects of oil and gas, that is, we investigate if their presence results in a less equal income distribution within the Russian regions. We achieve this aim by an empirical analysis. We establish that the link between oil and inequality as seen in the cross-country perspective has its counterpart in a similar link detectable in Russia.

Economic transition in Russia has caused shifts in allocation of wealth and resources both across (or between) regions and among (or within) their population. The former aspect of inequality has been investigated by several authors including Fedorov (2002), and Bradshaw and Vartapetov (2003). Here, we focus on the determinants of the latter aspect, on the factors affecting within-region dimension of inequality. We divide the regional populations into five income quintiles and use the shares in income of each of those in our analysis. We find oil and gas play a prominent and significant role in the process of wealth redistribution and accumulation within the Russian regions. The next section

\footnotetext{
${ }^{3}$ Also, given the international volatility of resource prices, the resource-based economy may ultimately be likely to suffer seriously in the case of price shocks (Sachs \& Warner 2001).

${ }^{4}$ On the impact of inequality on poverty in Russia, in regional perspective, see Kolenikov and Shorrocks (2005).

However, due to data limitations their estimations are based on one year only.
} 
summarises briefly some relevant literature concerning the issues of inequality and hydrocarbons resources, mainly referring to the Russian post-transitional experience. In the following section we move towards the econometric analysis and present the dataset used, variables included and results obtained.

\section{Hydrocarbons and inequality in Russia}

Oil and gas played an important part in Russian economic performance far before the beginning of transition. Hydrocarbons were a primary source of economic prosperity throughout the Soviet period. Oil production was already at a level of approximately 25 million barrels by 1920, and in the year 1987-1988 it peaked at 4.5 billion barrels, making the USSR the largest oil producer in the world. However, the early 1990s were characterised by a marked inefficiency in oil management in Russia. As a result of that, but also of the separation of some oil-producing former Soviet republics, production dropped back to third place among in the world, behind Saudi Arabia and the United States (Considine \& Kerr 2002).

It is more controversial to assess how much inequality there was in the Soviet era and to what extent it was linked to the natural resource endowment. Generally, during Soviet times, a very small share of incomes was derived officially from rents, as private property of natural resources and capital was almost non-existent (Milanovic 1998). On the one hand, this limited the impact of natural resources on inequality; on the other, the lack of private ownership rights facilitated enormous transfers of wealth from the extracting regions to the population centres in the European part of the country. Nevertheless, during the Soviet period, the production of oil and gas shifted gradually both to the east and to the south, and this has been seen as having a positive impact on equalisation of average income between the Soviet republics (but not necessary within republics), via new investment and improved technical and social infrastructure (Liebowitz 1987; Nechemias 1980). ${ }^{5}$ Commander et al. (1999) argue that Russia entered the transition period already with a significantly high level of inequality, which has then further increased as a result of the wealth transfers realised through privatisation (especially in the energy sector), changes in government expenditure and the growth in earnings dispersion.

Between-region disparities in oil and gas production and between-region income inequality in Russia

\footnotetext{
${ }^{5}$ However, it is far from obvious to what extent the shift towards the east (to Siberia and the Russian Far East) represented an efficient development path. The Soviet Union's central planners did not have effective optimisation criteria at their disposal. The geographical allocation of investment was disputed during the Soviet period (Schiffer 1985).
} 
Below, we present location data (Figure 1) and basic economic and social data (Table 1) of the 16 Russian regions with the largest oil and gas production per head. These are concentrated in the central part of Russia, along both sides of the Ural, with some extension towards the south, and Sakhalin in the Far East. Western Russia has no hydrocarbons. The largest producers per head are the Nenetskii Autonomous Okrug and the sub-regions of the Tyumen Oblast' (Yamalo-Nenetskii AO, Khanty-Mansiyskii AO). It is also in the Tyumen oblast' that we find the highest values of the indicators of inequality. Below, we discuss briefly some of the key contributions on between-region inequality and polarisation in Russia. ${ }^{6}$ Next, we will turn to the 'within' dimension concerning the heterogeneous impact of oil and gas on income groups within the regions that has not been explored much in the existing literature.

\section{[Please insert Figure 1 and Table 1 about here]}

Regional inequality across Russian regions may be explained using an array of factors. Fedorov (2002) considers polarisation between Western and Eastern regions, specificity of the national republics and ethnic Russian oblasti, comparison between urbanised and rural areas, and finally the role of the export orientation and economic openness of the regions. Using a dataset provided by Goskomstat Rosii, Fedorov (2002) carries a multidimensional analysis of inequality across Russian regions over the period 1990-1999. He confirms a continuous increase of inequality over the period 1991-1996. After 1996 the upward inequality trend became less steep and even reversed slightly in 1998. He establishes that between-regional differences were increasing due to the fact that both urbanised and exporter regions had grown faster in comparison to closed rural areas.

However, given the structure of Russian exports, exporting is the dimension which is closely related to the natural resource endowment. The share of hydrocarbons in total exports started from a level of $32 \%$ in 1998 and constantly increased until it reached $49.2 \%$ in 2003 (Gurvich 2004). Its share in merchandise exports reached over $60 \%$ in 2006 (Hanson 2007; OECD 2006). Also the ratio of hydrocarbons exports to GDP has been very high: it ranged from $10.4 \%$ in 1998 to $17.1 \%$ in 2003 . These figures are probably underestimated. According to the World Bank (2004) a consistent part of gas and oil revenues is misattributed to wholesale trade in order to escape taxation (Bradshaw 2006).

Bradshaw and Vartapetov (2003) confirm that inequality assumes a strong geographic connotation, with poorly performing regions facing problems in ensuring minimum living standards. Such a situation could be alleviated by the intervention of the central state administration smoothing the differences. However, state intervention has been

\footnotetext{
${ }^{6}$ For the discussion on the differences between the concepts of regional inequality and regional polarisation, see Fedorov (2002).
} 
insufficient. The allocation of federal assistance funds has not been based on clear principles, and this has allowed the development of a system of lobbying activities. In particular, the introduction of the Fund for Financial Support of the Regions (FFSR) in the mid-1990s failed to alleviate the spatial dimension of inequality. During the 1990s, the lack of economic and social logic in fiscal transfers between the federal government and the regions resulted from the chaotic nature of ad hoc compromises between the federal government and the regions, with national republics (such as Tatarstan, Bashkortostan and Yakutiya) being the key winners (Hahn 2005; Yenikeyeff 2008; Treisman 1998).

Using data provided by Goskomstat Rossii, Bradshaw and Vartapetov (2003) find for 1990-2001 that standard deviation in income falls sharply as one drops from the city of Moscow and the Tyumen region (the richest regions) and Ingushetia (the poorest). Similarly, for consumption, there was an increase in inequality led by prosperous regions such as Moscow, Samara, Tyumen, Perm and Lipetsk. In contrast, the spatial distribution of social and infrastructure indicators remained more equal.

Starting with the discussion of Russia in terms of the resource-based economy, Bradshaw (2006) discusses the role of the production of oil and gas and its regional aspects. Already during the Soviet era, natural resource rents were diverted from the oil and gas producing regions towards the European part of the Soviet Union. The implementation of this redistribution process was realised through the imposition of low prices on natural capital and high prices on machine capital. The hard currency inflows generated by the trade of natural resources were concentrated in the capital Moscow, to be then allocated strategically to the military industrial complex and to be used in exchange for grain and Western technologies to compensate for the failings of domestic agriculture and innovation processes correspondingly. On the other hand, in the producing regions, the development of oil and gas was implemented 'at the expense of socioeconomic infrastructure, not to speak of the environment, resulting in an extremely lopsided regional economy' (Glatter 2003, p.402). More importantly, a similar mechanism of regional relocation of rents can be detected after the transition, both by use of transfer pricing and through the taxation mechanism, where revenues are not channelled back to the regions of origin: 'the transfers involved are far more significant than any equalization payments through the fiscal federal structure' (Bradshaw 2006, p. 742).

Gaddy and Ickes (2005) explore the network of informal rent sharing, which developed around the hydrocarbons production and trade. There is no exact information on the true value of hydrocarbon rents and on the way they are redistributed. Both during the Soviet Era and after the transition to market economy, one of the main characteristics of value distribution has been non-transparency. An important channel of informal rent sharing is represented by corruption, which takes the form of a tax system parallel to the official one (Dininio \& Orttung 2004). Furthermore, the constant and wide gap between the domestic and international price of natural resources has contributed to the development of a complex price subsidies system. Companies also distort extraction cost to avoid 
formal taxation and use various forms of transfer prices to channel wealth away from where it could be taxed at source. Until the early 2000s, the oil companies were also highly effective in influencing the tax law for their benefit (Fortescue 2006; Yenikeyeff 2008).

Spatial dimension plays a major role in enhancing inequality in Russia. In general, among transition economies, the territorial extension has been found to be positively correlated with the level of inequality (Gerry \& Mickiewicz 2008; Bradshaw 2006): the larger the extension of a country, the higher the impact of regionally specific effects on income distribution. Thus, it is not surprising that in Russia the regional patterns of GDP per capita diverged dramatically from the beginning of the 1990s (Buccellato 2007).

It is interesting to compare the nature of regional disparities in Russia with the other two major emerging economies: India and China. As with Russia, in the past they experienced a significant dose of central planning, where the role of communist parties or left-orientated governments was dominant. All the three countries were characterised by significant disparities between regions. One common feature has been the increasing gap dividing rural and urban areas. In India and China, a great divide has been also arising between landlocked regions and coastal ones with the latter adapting better to the increased exposure to international markets. For Russia, as already discussed, natural resources have played a more significant role, affecting divergence in terms of both economic performance across regions and the disparities in income.

\section{Within-region inequality: rent seeking and political corruption}

According to Svedberg et al. (2006), the dimensions of within-region inequality exceed the between-regional dimensions. Moreover, marginally high or low average indicators computed at regional level can mask significant inequality on the lower level. For instance, the Tyumen region, which hosts much of the oil and gas administration, has a low average poverty rate (12\%), but in its southern, rural part, the poverty rate increases to $18 \%$ (UNDP 2007).

As discussed above, in the cross-country context, it has been found that large endowments of natural resources tend to go hand in hand with rent seeking behaviour. The natural resource sector is usually protected by huge barriers to entry, which leads to the strong position of producers. Where formal institutions are weak, high hydrocarbon-related rents may fuel corruption (Dininio \& Orttung 2004). In the Russian case, in the hydrocarbons-rich regions, the power struggle was typically limited to a few key players within the local oligarchy. After the initial wave of democratisation in the early 1990 s, the position of members of the political elite was increasingly defined by their relation to productive 
assets in the hydrocarbons sector (Glatter 2003). ${ }^{7}$ As documented by Glatter (2003) for the Tyumen Regional Duma, in $1990-1993,23 \%$ of seats were taken by employees and workers, $23 \%$ by professionals, $29 \%$ by economic leaders and middle level managers and $10 \%$ by administration officials. By the period 1997-2001, the representation of the first two groups had fallen to zero, and the representation of 'economic leaders' increased to $40 \%$ and of local administration to 20\%. A strong representation of big business in local institutions was also typical for other regions (Sakwa 2008).

While the recentralisation programme implemented in Russia in the early 2000s led to a loss of influence by regional leaders at the federal level, those local politico-economic elites that were co-opted by the Kremlin consolidated their position on the local level. 'As Russian critics of the [recentralisation] plan have pointed out, only partly facetiously, there are not enough KGB operatives from 1980s Leningrad to fill 89 top posts. ... Putin has ceded to regional leaders much leeway to run their regions as they see fit' (Slider 2005, pp. 183-184). ${ }^{8}$ As noted by Svedberg et al. (2006), '[S]ince September 2004 new gubernatorial appointments were made in 35 regions. In most cases, the governors have been appointed for a third or even fourth term, meaning that the new scheme has allowed them to bypass the two-term limit that existed under the previous system' (Svedberg et al. 2006, p. 10). This pattern implies more stability in the local political and economic structures of power and their increasingly undemocratic character.

To summarise the argument, we posit that local economic structures dominated by oil rents endowed business elites with enormous resources for forming the 'mutual hostages' structures with the state administration and for the corresponding distortion of democratic processes. That enabled big business to protect its economic interests. The only change in the 2000s was that the economic power was typically consolidated in the hands of federal corporate groups to cost of the regional corporate groups, many of which lost their autonomy (Yenikeyeff 2008). Evidence provided by Svedberg et al. (2006) shows that Khanty-Mansi Autonomous Okrug, which is the main centre of the Russian oil industry, takes fourth place on the regional list of state capture, ${ }^{9}$ and the neighbouring Tyumen region, where the oil and gas administration offices are located, takes the first place. Tyumen moved up to the top of the list in 2003, from a relatively low position in the mid-1990s.

One of the key channels through which state capture affects income distribution is through its detrimental effects on entry and entrepreneurship. Preferential treatment of big players comes at cost of smaller firms and the new

\footnotetext{
${ }^{7}$ A well-publicised case of an oil oligarch who became a governor of one of the Russian regions (Chukotka) was that of Mr Roman Abramovich, who was also one of the two controlling shareholders of Sibneft (with Boris Berezovsky), before the sale of the company to Gazprom in September 2005.

${ }^{8}$ See also Yenikeyeff (2008)

${ }^{9}$ State capture is defined as the situation in which outside interests are able to shape state institutions and policies to their advantage through corrupt transactions with public administration and politicans. It can be measured by preferential treatment obtained by firms: "tax breaks, investment credits, subsidies, subsidised loans, loans with a regional budget guarantee, official delays in tax payments, subsidised licencing free grants of state property, and special “open economic zone" status." (Svedberg et al., 2006, p.25). The results discussed here are based on an earlier empirical study by Yakovlev and Zhuravskaya (2004).
} 
entrants in particular. In turn, low entry of new firms implies that an important escape route out of low-income/poverty traps via new employment and self-employment is closed (Berkovitz \& Jackson 2006). In addition, there is no demand for labour and no wage competition from new entrants, which could have additional positive effects on incomes. Low entry coupled with a trend towards recentralisation is also very typical for the oil and gas industry in 2000 s (Kryukov \& Tokarev 2007). The negative association between entry and state capture for Russian regions is documented by Yakovlev and Zhuravskaya (2004).

In general, income distribution is shaped by the way the political process modifies both the primary economic distribution and the secondary income flows. The empirical link between authoritarian political structures and income inquality is documented for transition economies in cross country perspective by Gerry and Mickiewicz (2008). They arue that the authoritarian political structures are linked to non-competitive economic structures and that the latter inrease income inequality. A similar mechanism is likely to be found in the regional Russian perspective.

\section{Within-region inequality: labour market effects}

The political argument is directly connected with the economic one. Russia inherited a very concentrated industrial apparatus from the Soviet period and a difficult, protracted and painful process of reallocation of labour from obsolete industries to more profitable new ones followed the transition. In particular, the Stalinist centrally planned system implied the allocation of blue-collar workers and engineers to isolated mono-structural regions. In sharp contrast, the transition brought more dynamism into the metropolitan areas. Crucially, scarce inter-regional labour mobility coupled with regional protectionist policies impeded a natural process of arbitrage, making regional factor endowment predominant in shaping wage disparities. The competition in some sectors remained inadequate, especially where privatisation was not coupled with emergence of new entry businesses, and the local structures were dominated by one sector, hydrocarbons in particular (Glatter 2003). This situation led to forms of local monopsony in the labour market (Svedberg et al. 2006; Bignebat 2003). With respect to the oil and gas industry, the process of concentration and increasing entry barriers led to the spatial segmentation of production, where different companies enjoyed quasimonopolies within their respective territory of operation in the 2000s (Kryukov \& Tokarev 2007). Oil companies enjoy a monopsony position in recruiting labour, placing workers in a situation of dependency and weak bargaining power. This is an important factor which helps to explain why the local population is not sharing in the rents generated by the extracting industry as a result of direct, primary income distribution. In general, monopsony power leads to the persistence of wage differentials representing an important component of inequality (Bignebat 2003; Kislitsyna 2003). The factors contributing to this situation include low mobility of labour within the Russian borders, due to the high cost of migration (including administrative costs), lack of financial liquidity amongst workers and underdeveloped housing 
markets. In addition, local large firms provide fringe benefits and in-kind payments, which can 'be explained as an attachment strategy of firms: paying wages in non-monetary forms makes it hard for workers to raise the cash needed for leaving the firm/region' (Svedberg et al. 2006, p.14-15). Low mobility also affects high-skilled workers, and as a result, the regional labour market may exhibit characteristics of segmented labour markets, where the shortage of highskilled workers coupled with an abundance of low-skilled workers leads to wage inequality (Svedberg et al. 2006). Given the technological characteristics of the oil and gas industry and its organisational structures that emerged from the process of consolidation in the 2000 s, local outcomes of this nature are likely.

To shed some further light on the monopsony issue we carry out a comparison between two of the most important Russian companies-Gazprom and Rostelecom, both operating in sectors characterised by large rents (hydrocarbons and telecommunication). Controlling more than $60 \%$ of Russian gas reserves and $84.7 \%$ of national gas production, Gazprom alone accounted for 10.6\% of Russian GNP in 2006 (source: Gazprom in figures 2002-2006; http://www.gazprom.com/documents/Stat_Report_Eng.pdf; $\quad$ and Gazprom's Financial Reports http://www.gazprom.com/eng/articles/article20163.shtml). Rostelecom is the country's leading fixed-line telecommunications company, one of the biggest telecommunication companies in Russia, and operates nationwide with a network reaching approximately 200,000 kilometres in length (Source: Rostelecom's Financial Reports; http://www.rostelecom.ru/en/centr-invest/financial/public/).

Based on the financial statements of the two companies over the period 2002-2006, it clearly emerges that the share of profits in value added as compared with the corresponding share of wages is much higher in Gazprom. In the case of Rostelecom the wages cost is always higher than the amount of gross profits. That amounts to a striking intersectoral difference, which is further reinforced by the differences in the internal composition of wage expenses, in terms of the share of the remuneration of senior management and directors in the total amount of wages and salaries. Over the period 2002-2006 this share ranged from $0.6 \%$ to around $2.4 \%$ for Rostelecom and from around $10 \%$ to approximately $13 \%$ for Gazprom, implying a much lower share for workers in comparison with the management apparatus in valueadded in the hydrocarbons sector (Figure 2).

[Please insert Figure 2 about here] 


\section{Redistribution}

Disparities generated in the labour market could be offset by redistribution through the tax system and government expenditure. Due to the general increase of international hydrocarbon prices before the reversal of the trend in 2008 , revenues from custom duties strongly increased in the early 2000s and, as a result, their share in total revenues went up from $7.1 \%$ in 1999 to $15.8 \%$ in 2004 (Ellman 2006). While oil price growth amounted to 191\% between 2002 and 2007 , the corresponding growth in custom duty was $982 \%$. A parallel growth in tax on mineral production between 2002 and 2007 amounted to $353 \%$ (Kryukov \& Tokarev 2007). Hydrocarbon revenues have been targeted for the creation of the so-called stabilisation fund, set up to prevent a new financial crisis similar to the one experienced in August 1998. In January 2006 the stabilisation fund reached a total of 1,459.1 billion rubles (Ellman 2006, p.41-43).

DeBardeleben (2003) has considered the balance of financial flows between the regions and the centre (the difference between the total amount of tax revenues collected in the regions and expenditure of the regional government) in four different regions (Stavropol'skii krai, Orlovskaya Oblast', Nizhegorodskaya Oblast' and KhantyMansiiskii Autonomous okrug) over the period 1996-1998. The region of Khanty-Mansiiskii Autonomous okrug, which is the main centre of the Russian oil industry, contributes far more to the federal budget than the three remaining regions. However, despite the relevant amount of tax revenues generated by the hydrocarbons sector, it is not clear how

they are redistributed, especially across regions. Performing an ordinary least square regression with robust standard errors on a cross-section of 87 Russian regions for the year 2005, we find an insignificant negative relation between average monthly transfers to households per capita and percentage of people living under the poverty threshold (Figure 3). These results seem to suggest that the fiscal transfers are not targeting the poor, and are therefore not decisive in reducing the gap separating the richest and the poorest, which is likely to be the highest in hydrocarbons producing regions due to the economic and political factors discussed above.

\section{[Please insert Figure 3 about here]}

To summarise, we posit the following. The distribution of income both between and within regions is strongly affected by the rents generated by hydrocarbons extraction and trade, which are supported by the economic and political structures. The distributional effects are partly driven by the technological characteristics of the extraction processes, where capital-intensive firms create pockets of limited numbers of well-paid jobs. However, they are enhanced by the monopsonistic position of these companies against both the bulk of their workers and the local labour force, from which the employees are drawn. The strong local position of these companies is protected by the dominant position of the key big business players in the political structures. 
In addition, a significant part of resource rents is transferred away from the extraction region, leaving less to be shared directly with local communities. This would not be a problem per se, and could even be welcomed if federal spending were to compensate for the local distortions. However, existing evidence demonstrates that while the government share in the oil and gas rents has been on the increase, it has not been accompanied by well-targeted social transfers, which could return to the communities some of the wealth from the actual physical resources in their neighbourhood. Taking all these factors together, we can explain the paradox, which is that the regions where the oil and gas resources are located, are also characterised by the more extreme social contrasts.

The literature provides cross-country evidence that oil and gas endowment is associated with an increase in inequality, and the same factor may play a significant role in the cross-regional perspective for Russia. Accordingly, we intend to establish empirically whether, in addition to the dimension of hydrocarbons-driven inequality between regions in Russia, we also see an increase in inequality within the regions of extraction. In the next section we introduce the empirical methodology we wish to implement for this purpose.

\section{Hydrocarbons and inequality in the Russian regions}

\section{Measuring inequality between and within Russian regions}

Inequality is a multidimensional concept. It includes a wide range of aspects, such as wealth, consumption, access to health, education and other public services. However, any empirical analysis is always limited by the availability of data and in our study we use the broadest and the most used concept of inequality, concerning divergence in income levels. We first construct a bi-dimensional measure of inequality between and within regions to demonstrate the role played by oil and gas. To measure inequality between regions we use the Theil Statistic. We take the logarithm of the ratio of the average regional income to the average income in the country (which is a relative measure of income gap between a given regional average and the country average; see the first term in the formula below). This is multiplied by the ratio of the average regional income to the average income (which can be considered as a proxy of the average share in country income; see the second term below). Finally, we multiply it by the share of each region's population in the Russian population as a whole (to capture the importance of regional contribution to the overall inequality in Russia; see the third term below). Correspondingly, the formula is:

Theil $=\ln \left(\frac{\text { Average_Re gional_Income }}{\text { Average_National_Income }}\right) \times \frac{\text { Average_Re gional_Income }}{\text { Average_Country_Income }} \times \frac{\text { Re gion_Population }}{\text { Total_Population }}$ 
The Theil's measure of inequality that we derived captures the spatial component of inequality, showing the size of the contribution of each individual region to the total amount of inequality between regions in the Russian Federation. Figure 4 below shows the importance of the role played by the west Siberian region (the two autonomous administrative entities of Khanty-Mansiskii Autonomous Okrug and Yamalo-Nenetskii Autonomous Okrug, both in the Tyumen Oblast'). This region produces approximately one half of the total amount of hydrocarbons in Russia. The administrative organisation of the Tyumen area is deeply connected with the distribution of natural resources and with the economic structure of their production. The Khanty-Mansiskii Autonomous Okrug represents the main centre of the Russian Oil industry, while Yamalo-Nenetskii Autonomous Okrug is the area where the highest share of gas production takes place. The remaining portion of the territory is the Tyumenskaya Oblast' 'proper', consists mainly of Tyumen, the capital city, plays the complementary role of onward hydrocarbons transmission and provides the strategic base of oil and gas administration offices (Glatter 2003). Galbraith et al. (2004) argue that the prominent contribution of the Tyumen region to inequality between regions in Russia reflects the advantage of export oriented areas with respect to other regions in attracting strong currency revenues, and of urban entities with developed systems of services. However, we demonstrate below that also when controlling for the general amount of exports and the share of services, oil and gas still continue to play an important role in explaining inequality.

\section{[Please insert Figure 4 about here]}

\section{Inequality within regions: data, model specifications and methodology}

Goskomstat Rossii provides data at the regional level for the annual share of income acquired by each quintile of the population. Data is available for the period 2000-2004. Our measure of inequality can now be computed alternatively either as the share acquired by the top quintile, by the bottom quintile or the difference between the share of income of the top quintile of the population in each of the regions and the shares of the remaining four quintiles of the population, separately considered.

Over the period 2000-2004 we can rely on a complete balanced panel for 86 Russian regions. To avoid double counting, where both regional level data and sub-regional level data (for autonomous regions) are reported, we use the residuals obtained by subtracting the reported lower level units from the higher level regional units. For example, instead of using the figures for the whole Tyumen region, we use a residual obtained by deducting the figures for Khanty-Mansiiskii Autonomous Okrug and Yamalo Nenetskii Autonomous Okrug from the figures provided for the whole region. We also 
have to exclude the Chechen Republic because of the lack of available data, and the capital, Moscow, because it is an outlier and presents specific characteristics not comparable with the rest of the Russian Federation. ${ }^{10}$

One further remark is necessary. The quality of the data at the regional level is sometimes questionable and this raises the issue of the reliability of regional datasets. In the case of the Russian Federation, Goskomstat Rossii provides the data as it was collected by the local authorities. Solanko (2003) raises doubts about the precision of regional data collection in Russia. Yemtsov (2003) also raises the possibility of inconsistencies between national and regional methodologies of producing data which, for example, would prevent disaggregation of national data into regional components. However, the methodology used by Goskomstat has constantly improved and has been standardised so that it conforms more closely to international benchmarks for the period under consideration. Moreover, while recognising the possible drawbacks in using Goskomstat data, it is the only complete dataset that can be used for our purposes.

As dependent variables we first use the percentage shares of income for each regional population quintile. In particular, the share of income of the richest $20 \%$ is an important indicator of income distribution. ${ }^{11}$ As our robustness check, we also utilise the differences between the percentage shares of highest income quintile of the population and the corresponding shares of the lower quintiles. All are computed at the regional level, that is, they capture the withinregion inequality.

We consider the production of oil and gas tonnes standardised by the number of people living in each region (P_OIL\&GAS) as the core variable for our analysis. To reinforce our results, we introduce some control variables that have been shown in the economic literature as playing an important role in affecting both income growth and distribution across individuals and spatial entities. We end up by considering five control variables.

First, differences in wages and hence income inequality can be explained as a consequence of the heterogeneous distribution of human capital across people and space. Lukyanova (2006) concludes that inequality becomes more severe where the share of workers with low education levels is higher. The relation between inequality and investment in human capital is ambiguous in the economic literature (Aghion et al. 1999). However, despite the uncertainty relating to the long-run impact of investment in human capital on inequality, the link between these two variables has been widely discussed and we introduce the corresponding variable using a proxy (ENROLMENT_RATE). This variable represents the percentage of children enrolled in primary school out of the population of children at the corresponding age. The primary education variable has been used in empirical studies on determinants of economic development (Barro, 1991; Alesina \& Rodrik 1994).

\footnotetext{
${ }^{10}$ We ran our models both without Moscow and with a Moscow dummy variable and found little difference between the results. All are available on request. Consistent with the previous discussion, it is important to note that Moscow remains a major beneficiary of hydrocarbons-related rents.

${ }^{11}$ For discussion of this, see, for instance, Reuveny \& Li (2003).
} 
Furthermore, we introduce two other control variables. The first is the logarithm of the regional GDP (I_RGDP). After Kuznets $(1955 ; 1963)$ revealed the inverted U-shaped relationship between the two variables, there have been numerous studies testing the link. If the debate about the direction by which one variable affects the other remains still open, the emerging consensus in the recent literature is that income and inequality seem to vary endogenously (Lundberg \& Squire 2003). In order to alleviate the problem we make use of the System Generalised Method of Moments (GMM), which has been proved to be robust with respect to endogenous variables thanks to its use of instruments: past values of first differences are used to instrument current levels of variables, and vice versa.

In addition, we control the natural logarithm of total exports denominated in dollars (I_EXPORT). After the 1998 financial crises and the consequent strong devaluation of the ruble, the increase in inequality was affected by polarisation between regions with access to international trade and those that relied on internal market economic activities. The gap increased especially when goods were produced at costs denominated in roubles and sold at hard currency prices on the international markets. Galbraith et al. (2004) conclude that relative income rose more sharply in regions enjoying hard currency export earnings. However, this increase in income was not necessarily shared evenly by the local population, which could lead to higher inequality within regions. Controlling for exports is important, otherwise testing of our hypothesis on the impact of hydrocarbons could suffer from the omission of a related variable, thereby creating a bias.

The results of Fedorov (2002) suggest that together with exports, the degree of urbanisation has played a very important role in enhancing disparities across regions. Such a result can be explained by the existence of more developed services sectors in regions with higher degrees of urbanisation. People working in newly privatised services usually benefit from higher wages with respect to workers in manufacturing industries and especially to low-skilled labour in rural areas. Hence, we include also the share of services in total production (SERV) as our explanatory variable for the within-region dimension of inequality.

Summarising, we end up with the following two main specifications. The first is where the dependent variables are the shares in regional income of the five quintiles of the regional population. The second relates to the differences between the shares of the top quintile and the lower ones. Thus we have:

$$
\begin{aligned}
& \text { Qunt }{ }_{-} j-t h=\alpha_{1}+\alpha_{2}\left(\mathrm{P} \_ \text {OIL } \& \text { GAS }\right)_{\mathrm{i}, \mathrm{t}}+\alpha_{3}(\text { ENROLMENT_RATE })_{\mathrm{i}, \mathrm{t}} \\
& +\alpha_{4}\left(1_{-} \mathrm{RGDP}\right)_{\mathrm{i}, \mathrm{t}}+\alpha_{5}\left(1_{-} \text {EXPORT }\right)_{\mathrm{i}, \mathrm{t}}+\alpha_{6}(\mathrm{~S} E R V)_{\mathrm{i}, \mathrm{t}}+\varepsilon_{i, t}
\end{aligned}
$$


Dist_5-th_j-th $=\alpha_{1}+\alpha_{2}\left(\mathrm{P}_{-} \text {OIL \& GAS }\right)_{\mathrm{i}, \mathrm{t}}+\alpha_{3}(\text { ENROLMENT_RATE })_{\mathrm{i}, \mathrm{t}}$

$+\alpha_{4}\left(1_{-} \mathrm{RGDP}\right)_{\mathrm{i}, \mathrm{t}}+\alpha_{5}\left(1_{-} E X P O R T\right)_{\mathrm{i}, \mathrm{t}}+\alpha_{6}(\mathrm{~S} E R V)_{\mathrm{i}, \mathrm{t}}+\varepsilon_{i, t}$

where $i$ represents a region, $t$ a year and $j$ the income quintile (1-5). Qunt $j$-th relates to the share in income of the corresponding quintile. Dist $5-t h{ }_{-} j-t h$ relates to the four differences of percentage GDP share between the fifth percentile and each of the remaining lower four income groups (with $j=1,2,3,4)$. For the five years considered we can rely on a complete balanced panel for 86 Russian regions.

We now briefly discuss the choice of the appropriate methodology to obtain estimates of the models presented above. We need to control for regional specific effects unaccounted for by our set of explanatory variables. In addition we face a potential simultaneity bias, as some of our explanatory variables may be affected by our dependent variable (ENROLMENT_RATE and I_RGDP for example). We address both problems by choosing the System GMM methodology as introduced by Arellano and Bover (1995) and Blundell and Bond (1998; 2000). In addition, with System GMM, we also apply the robust standard errors, implying a further improvement in the quality of our estimations.

In addition to our preferred models, we also show results obtained by testing for alternative dependent variables using the same benchmark model as specified in equation (1). In particular we use (a), the Gini index (GINI); (b) the coefficient of differentiation in income between the richest $10 \%$ and the poorest $10 \%$ of the population (Coeff_Diff_Income); and (c) the Theil statistic (calculated using the formula as depicted above based on data on regional GDP and population as provided by Goskomstat) (THEIL). The first two measures have been discussed already. Data for the third proxy for inequality is provided by Goskomstat together with the Gini Index and we use it as an alternative measure of the gap between poorest and richest percentile of the population. However, for the Gini index and the coefficient of differentiation in income we only have three years available (2003-2005) and this prevents us from applying the dynamic panel data specifications. For such a short span of time we apply a so-called 'between effects' estimator, based on three years averages of all the variables included in the model.

Results

Our main hypothesis relates to the hydrocarbons as a factor enhancing inequality within regions. All our specifications confirm the important role of oil and gas production in enhancing divergence and inequality within regions.

We start with presenting results obtained with the percentage shares of each quintiles of the population as the dependent variables and implementing the System GMM methodology (Table 2). It turns out clearly that oil and gas 
(P_OIL\&GAS) tend to enrich the highest quintile of the population most; in contrast, for all the remaining four quintiles of the population the variable exhibits a negative relation with the correspondent share of wealth. The effect of the variable representing the hydrocarbons production is also robust to the introduction of additional control variables such as the logarithm of regional GDP (I_RGDP) and the logarithm of the amount of exports (I_EXPORT). Interestingly, the gains from exports are more widely shared. On the other hand, the share of services in total regional production (SERV) seem to benefit the richest percentile of the population most, a result that could be linked to the presence of entry barriers.

[Please insert Table 2 about here

We move next to the analysis based on the gaps between the share of wealth owned by the richest quintile and the remaining four quintiles individually taken (Table 3). As this is a more restrictive test of our hypotheses, the services indicator is no longer significant, but the key variable which remains very significant in exacerbating differences across different quintiles is oil and gas. We should also emphasise that for both models, all the tests seem to confirm the validity of specification: the lag of the dependent variable is always very significant, the autocorrelation of the first order is always significant but, importantly, the second order autocorrelation is in contrast never detected, and the overidentifying restriction test always provides good results.

\title{
[Please insert Table 3 about here]
}

Finally, in Table 4 we present results obtained with three additional dependent variables as proxies for inequality implementing the between effect regression. The three columns of the table reports results for (1) the Gini index, (2) the coefficient of differentiation in income between the richest $10 \%$ and the poorest $10 \%$ of the population and (3) the Theil's t statistic, respectively. The only variable which exhibits a positive and highly significant impact on inequality is again the hydrocarbons production. Services and the regional output are found to have a positive and significant impact on inequality in two out of three specifications. The enrolment rate and exports lose their explanatory power.

[Please insert Table 4 about here]

\author{
Concluding remarks
}


Russia is the largest country on earth $\left(11.5 \%\right.$ of its surface, $\left.17,075,200 \mathrm{~km}^{2}, 6,591,027 \mathrm{mi}^{2}\right)$, almost twice as large as Canada, the US and China, and more than twice as large as Brazil and Australia. Despite the recent recentralisation, its geographical diversity is still matched by institutional, economic and social diversity. It is for this reason that some of the theoretical tools developed to understand cross-country variation may be applied, as we have done, to analyse variation on the regional level in Russia (Popov 2001). We focus on hydrocarbons endowment and argue that the regularities observed on the cross-country level apply to Russian regions as well. In this novel perspective, we test empirically the determinants of intra-regional inequality in Russia, applying robust dynamic panel data estimators. We find that regions where oil and gas are produced tend to experience higher levels of income inequality in striking resemblance to cross-country results.

Why do our findings matter? Even though inequality is not the same as poverty, Kolenikov and Shorrocks (2005) documented that along the low level of income, inequality is also an important determinant of poverty in Russia. In the hydrocarbons perspective, these two factors work in the opposite direction. On the one hand, the oil-rich and gasrich regions are characterised by higher average incomes; on the other, they are characterised by important intraregional disparities. This is well understood in Russia, and one can also see that government initiatives address some of the problems, examples of which include a 'self-sufficiency' target programme launched in Tyumen Region in 2007 (UNDP 2007). More could be done in this respect and the efficient solution would require tackling the problems at their roots. We argue, that in a striking resemblance to country-level analysis, hydrocarbon rents provide big business with concentrated wealth which has been used to derail the democratic processes initiated in Russia in the early 1990 s. Glatter (2003) provides a striking example of how this mechanism had operated at the local level and resulted in a high level of integration between the local oil industry and local political elites achieved by the early 2000 s. It seems that the recent recentralisation drive changes the local balance of power, with a shift from regional corporate groups to federal corporate groups and a stronger position of the federal government (Yenikeef 2008). However, while the local elites coopted by the federal administration give up their ambitions at the federal level and help the president and the ruling party to achieve the expected elections results at the local level, they are becoming more protected from the potential local political competition under a new implicit political contract (or 'mutual hostages' situation, to use the terminology of Dininio and Orttung 2004).

Thus, with the return to statism from 2003 onwards (Hanson 2007; OECD 2006), the organisational features of the big players evolve, but the mechanism remains similar. Åslund (2005) states that after the new reorganisation of the energy sector, the huge oil revenues have corrupted the top of the state administration and the market reforms needed to enhance economic efficiency have become suboptimal for the top officials. There is a danger of a renewed state energy monopoly, implying the shift from a system of oligarchs' control to a system of bureaucrats' control of hydrocarbons 
revenues. The identity of the key players could change at the local level, but not the basic mechanism of political capitalism. As documented by Svedberg et al. (2006), oil and gas regions open the ranking of regions ordered by the extent of state capture. This pattern has become clearer now than it was in the late 1990s. Big companies may follow a seemingly paternalistic approach offering fringe benefits and in-kind payments to its employees. However, the problem is that this policy has a detrimental effect upon labour mobility and therefore-indirectly—upon income distribution. Even more seriously, state capture at the regional level is strongly correlated with weak entrepreneurship and low entry (Svedberg et al., 2006). This produces inequality as it closes some efficient channels to exit poverty and makes the monopsonistic features of the labour market even stronger. As explicitly explained by one of the regional officials in an interview, entry is perceived as bad to local businesses as it may create competition driving wages up (Estrin \& Prevezer 2006).

There are some important extensions to our analysis that we have not yet followed. It would be an interesting extension of current research to investigate to what degree the same pattern applies to other post-Soviet republics. In particular, there is evidence that a similar situation of regional inequality associated with oil extraction may be present in Kazakhstan (Kaiser 2006). In addition, since, as of the end of 2008, hydrocarbons-related rents are shrinking due to lower world market prices, it would be fascinating to discover the impact of this on inequality between regions and within regions in the Russian Federation. However, this is beyond the scope of the current analysis.

In summary, we stress the interactions between economic structures, political processes and social outcomes. We demonstrate that oil and gas lead to inequality at the local level and argue that there is evidence that the link between the two is via a corrupted political mechanism and distorted economic institutional frameworks. However, as observed by Bradshaw (2006), the example of Norway demonstrates that oil does not need to produce socially undesirable effects if coupled with an efficient political mechanism. There is nothing deterministic or inevitable about the future in our conclusions. Russia is too large and complex to make strong assumptions about the sustainability of the current trends. Its potential for change should not be underestimated. 


\section{References}

Aghion, P., Caroli, E. \& Garcia-Penelosa, C. (1999) 'Inequality and Economic Growth: The Perspective of New

Growth Theory', Journal of Economic Literature, 37, 4, pp. 1615-1660.

Alesina, A. \& Rodrik, D. (1994) 'Distributive Politics and Economic Growth', Quarterly Journal of Economics, 109, 2 , pp. $465-490$.

Arellano M. \& Bover, O. (1995) ‘Another Look at the Instrumental Variable Estimator of Error-Components Models’, Journal of Econometrics, 68, 1, pp. 29-52.

Åslund, A. (2005) 'Putin's Decline and America's Response', Policy Brief, Carnegie Endowment for International Peace, 2005.

Barro, R. (1991), ‘Economic Growth in a Cross Section of Countries', Quarterly Journal of Economics, 106, 2, pp. 407444.

Berkowitz, D. \& Jackson, J. E. (2006) 'Entrepreneurship and the Evolution of Income Distributions in Poland and Russia', Journal of Comparative Economics, 34, 2, pp. 338-356.

Bignebat, C. (2003) 'Spatial dispersion of wages in Russia: does transition reduce inequality on regional labour markets?', TEAM University of Paris I \& CNRS, mimeo.

Blundell, R. \& Bond, S. (1998) 'Initial Conditions and Moment Restrictions in Dynamic Panel Data Models', Journal of Econometrics, 87, 1, pp. 115-143.

Blundell, R. \& Bond, S. (2000) 'GMM estimation with persistent panel data: an application to production functions', Econometric Reviews, 19, 3, pp. 321-340.

Bradshaw, M. (2006) 'Observations on the Geographical Dimensions of Russia's Resource Abundance,' Eurasian Geography and Economics, 47, 6, pp. 724-746.

Bradshaw, M. J. \& Vartapetov, K. (2003) ‘A New Perspective on Regional Inequalities in Russia,' Eurasian Geography and Economics, 44, 6, pp. 403-429.

Buccellato, T. (2007) Convergence across Russian Regions: A Spatial Econometrics Approach, Discussion Paper 70 (London, CEFIMS SOAS University of London).

Commander, S., Tolstopiatenko, A. \& Yemtsov, R. (1999) 'Channels of Redistribution-Inequality and poverty in the Russian transition,' The Economics of Transition, 7, 2, pp. 411-47.

Considine, J. I. \& Kerr, W. A. (2002) The Russian Oil Economy (Cheltenham \& Northampton, MA, Edward Elgar).

Corden, W. M. \& Neary, J. P. (1982) 'Booming Sector and De-Industrialisation in a Small Open Economy,' The Economic Journal, 92, 368, pp. 825-848. 
Corden, W. M. (1984), 'Booming Sector and Dutch Disease Economics: Survey and Consolidation', Oxford Economic Papers, 36, 3, pp. 359-380.

Davis, G. \& Tilton, J. E. (2005) 'The Resource Curse', Natural Resources Forum, 29, 3, pp. 233-242.

DeBardeleben, J. (2003) 'Fiscal Federalism and How Russians Vote', Europe-Asia Studies, 55, 3, pp. 339-363.

Dininio, P. \& Orttung, R. (2004) 'Explaining Patters of Corruption in the Russian Regions', William Davidson Institute Working Paper No 727, University of Michigan.

Eastwood, R. K. \& Venables, A. J. (1982) 'The Macroeconomic Implications of a Resource Discovery in an Open Economy', The Economic Journal, 92, 366, pp. 285-299.

Ellman, M. (ed.) (2006) Russia's Oil and Natural Gas- Bonanza or Curse? (London, Anthem Press).

Estrin, S. \& Prevezer, M. (2006) 'On the Role of Institutions in Firm Entry and Survival in Emerging Markets; A CrossCountry Case Study Approach', paper presented at CNEM seminar, London Business School, mimeo.

Federov, L. (2002) 'Regional Inequality and Regional Polarization in Russia, 1990-99', World Development, 30, 3, pp. 443-456.

Fortescue, S. (2006) Russia's Oil Barons and metal Magnates. Oligarchs and the State in Transition (Houndmills, Palgrave Macmillan).

Gaddy, C. G. \& Ickes, B. W. (2005) 'Resource Rents and the Russian Economy,' Eurasian Geography and Economics, 46,8, pp. 559-583.

Galbraith, J. K., Krytynskaia, L. \& Wang, O. (2004) 'The Experience of Rising Inequality in Russia and China during the Transition', The European Journal of Comparative Economics, 1, 1, pp. 87-106.

Gerry, C. J. \& Mickiewicz, T. M. (2008) 'Inequality, Democracy and Taxation: Lessons from the Post-Communist Transition,' Europe Asia Studies, 60, 1, pp. 89-113.

Glatter, P. (2003) 'Continuity and Change in the Tyumen' Regional Elite 1991-2001', Europe-Asia Studies, 55, 3, pp. $401-435$

Gurvich, E. T. (2004) 'Makroekonomicheskaya otsenka roli rossiiskogo neftegazovogo sektora', Voprosy Ekonomiki, 10.

Gylfason, T. \& Zoega, G. (2002) Inequality and Economic Growth: Do Natural Resources Matter?, Working Paper 712

(5) (Munich, CESifo).

Hahn, G. (2005) 'Reforming the Federation', in White, S., Gitelman, Z. \& Sakwa, R. (eds) (2005) Developments in Russian Politics 6 (Houndmills, Palgrave Macmillan), pp. 148-167.

Hanson, P. (2007) 'The Russian Economic Puzzle: Going Forwards, Backwards or Sideways?', International Affairs, 83, 5, pp. 869-889. 
Kaser, M. (2006) ‘Sustaining Growth: A Prospectus For Labour Market Policies In Kazakhstan’, Russian And Eurasian Centre, St Antony's College, University of Oxford, mimeo, 2006.

Kislitsyna, O. (2003) Income Inequality in Russia during Transition-How Can It Be Explained?, Working Paper 03/08 (Moscow, Economics Education and Research Consortium).

Kolenikov, S. \& Shorrocks, A. (2005) 'A Decomposition Analysis of Regional Poverty in Russia', Review of Development Economics, 9, 1, pp. 25-46.

Kryukov, V. \& Tokarev, A. (2007) Neftegazovye Resursy v Transformeremoi Ekonomike (Novosibirsk, Nauka-Center).

Kuznets, S. (1955) ‘Economic Growth and Income Inequality’, American Economic Review, 45, 1, pp. 1-28.

Kuznets, S. (1963) 'Quantitative Aspects of the Economic Growth of Nations', Economic Development and Cultural

Change, 11, pp. 1-80.

Leite, C. A. \& Weidman, J. (1999) Does Mother Nature Corrupt? Natural Resources, Corruption, and Economic Growth, Working Paper WP/99/85 (Washington, DC, IMF).

Liebowitz, D. (1987) 'Soviet Investment Strategy: A Further Test of the "Equalization Hypothesis"”, Annals of the Association of American Geographers, 77, 3, pp. 396-407.

Lukyanova, A. (2006) Wage Inequality in Russia (1994-2003), Working Paper 06/03 (Moscow, Economics Education and Research Consortium).

Lundberg, M. \& Squire, L. (2003) 'The Simultaneous Evolution of Growth and Inequality', Economic Journal, 113, 487, pp. 326-344.

Milanovic, B. (1998) Income, Inequality and Poverty during the Transition from Planned to Market Economy (Washington, DC, World Bank).

Nechemias, C. (1980) 'Regional Differentiation of Living Standards in the RSFSR: the Issue of Inequality', Soviet Studies, 32, 3, pp. 366-378.

OECD (2006) Economic Surveys: Russian Federation (Paris, Organisation for Economic Cooperation and Development).

Popov, V. (2001) 'Reform Strategies and Economic Performance of Russia’s Regions', World Development, 29, 5, pp. $865-886$.

Reuveny, R. \& Li, Q. (2003) 'Economic Openness, Democracy, and Income Inequality. An Empirical Analysis', Comparative Political Studies, 36, 5, pp. 575-601.

Sachs, J. D. \& Warner, A. M. (2001) 'Natural Resources and Economic Development-The curse of natural resources', European Economic Review, 45, 4-6, pp. 827-838.

Sakwa, R. (2008) Putin. Russia's Choice (London, Routledge). 
Sala-I-Martin, X., Doppelhofer, G. \& Miller, R. I. (2004) 'Determinants of Long-Term Growth: A Bayesian Averaging of Classical Estimates (BACE) Approach', American Economic Review, 94, 4-6, pp. 813-835.

Schiffer, J. (1985) 'Interpretations of the issue of “inequality” in Soviet regional policy debates', International Journal of Urban and Regional Research, 9, 4, pp. 508-532.

Slider, D. (2005) 'Politics in the Regions', in White, S., Gitelman, Z. \& Sakwa, R. (eds.) (2005) Development in Russian Politics 6 (Houndmills, Palgrave Macmillan), pp. 168-185.

Solanko, L. (2003) An Empirical Note on Growth and Convergence Across Russian Regions, Discussion Paper 9 (Helsinki, Bank of Finland, Institute for Economies in Transition).

Svedberg, M., Ono, J. \& Mosina, O. (2006) (eds.) Unleashing the Potential. Growth and Investment in Russian Regions (Moscow, Centre for Economic and Financial Research and Stockholm, Stockholm Institute of Transition Economics). Treisman, D. (1998) 'Deciphering Russia’s Federal Finance: Fiscal Appeasement in 1995 and 1996', Europe Asia Studies, 50, 5, pp. 893-906.

UNDP (2007) Russian Regions: Goals, Challenges, Achievements. Human Development Report. Russian Federation 2006/2007 (New York, United Nations Development Programme).

Yakovlev, E. \& Zhuravskaya, E. (2004) State Capture and Controlling Owners of Firms, Working Paper 44 (Moscow, CEFIR).

Yemtsov, R. (2003) Quo Vadis? Inequality and Poverty Dynamics across Russian Regions', Discussion Paper 67

(Helsinki, WIDER).

Yenikeyeff, S. (2008) The Battle for Russian Oil: The Kremlin, Governors and Oligarchs (Oxford, Oxford University Press), forthcoming.

World Bank (2004) Country Economic Memorandum for Russia (Washington, DC, World Bank) 
TABLE 1. REGIONS OF RUSSIA WITH LARGEST OIL AND GAS PRODUCTION PER HEAD. BASIC SOCIO-ECONOMIC DATA

\begin{tabular}{|c|c|c|c|c|c|c|c|c|}
\hline & $\begin{array}{l}\text { oil \& gas } \\
\text { production } \\
\text { (tonnes) / } \\
\text { population } \\
\text { (2000-2005 } \\
\text { average) }\end{array}$ & $\begin{array}{l}\text { share of } \\
\text { income: } \\
\text { richest } 20 \% \\
\text { population } \\
\text { (2000-2005 } \\
\text { average) }\end{array}$ & $\begin{array}{c}\text { share of } \\
\text { income: } \\
\text { poorest } 20 \% \\
\text { population } \\
(2000-2005 \\
\text { average) }\end{array}$ & $\begin{array}{c}\text { total } \\
\text { population } \\
\text { in thousands } \\
\text { (2002 } \\
\text { census) }\end{array}$ & $\begin{array}{c}\text { population } \\
\text { as } \\
\% \text { of } \\
\text { Russia } \\
\text { (2002 } \\
\text { census) } \\
\end{array}$ & $\begin{array}{l}\% \text { share of } \\
\text { services } \\
\text { in production } \\
(2000-2005 \\
\text { average })\end{array}$ & $\begin{array}{c}\% \text { share of } \\
\text { agriculture } \\
\text { in } \\
\text { production } \\
\text { (2000-2005 } \\
\text { average) }\end{array}$ & $\begin{array}{c}\text { Regional } \\
\text { GDP as } \% \text { of } \\
\text { Russia } \\
\text { (2000-2004 } \\
\text { average) }\end{array}$ \\
\hline \multirow{2}{*}{$\begin{array}{l}\text { Astrakhanskaya Oblast' } \\
\text { Evenkiiskii AO }\end{array}$} & 3.9 & $41.7 \%$ & $7.0 \%$ & 1,005 & $0.69 \%$ & $41.7 \%$ & $5.5 \%$ & $0.47 \%$ \\
\hline & 3.1 & $44.3 \%$ & $6.1 \%$ & 18 & $0.01 \%$ & $78.9 \%$ & $5.1 \%$ & $0.02 \%$ \\
\hline \multirow{3}{*}{$\begin{array}{l}\text { Khanty-Mansiiskii } \\
\text { Nenetskii AO } \\
\text { Orenburgskaya Oblast' }\end{array}$} & 155.0 & $48.8 \%$ & $4.9 \%$ & 1,433 & $0.99 \%$ & $23.4 \%$ & $0.3 \%$ & $7.30 \%$ \\
\hline & 176.2 & $46.8 \%$ & $5.4 \%$ & 41 & $0.03 \%$ & $15.5 \%$ & $0.9 \%$ & $0.22 \%$ \\
\hline & 3.8 & $40.3 \%$ & $7.5 \%$ & 2,180 & $1.50 \%$ & $48.8 \%$ & $5.5 \%$ & $1.16 \%$ \\
\hline \multirow{2}{*}{$\begin{array}{l}\text { Permskaya Oblast' } \\
\text { Resp. Bashkortostan }\end{array}$} & 6.9 & $46.1 \%$ & $5.6 \%$ & 1,449 & $1.00 \%$ & $46.8 \%$ & $14.7 \%$ & $2.02 \%$ \\
\hline & 2.8 & $44.3 \%$ & $6.1 \%$ & 4,104 & $2.83 \%$ & $34.1 \%$ & $10.9 \%$ & $2.37 \%$ \\
\hline Respublika Komi & 9.6 & $47.1 \%$ & $5.3 \%$ & 1,019 & $0.70 \%$ & $42.4 \%$ & $1.8 \%$ & $1.01 \%$ \\
\hline \multirow{2}{*}{$\begin{array}{l}\text { Respublika Tatarstan } \\
\text { Sakhalinskaya Oblast' }\end{array}$} & 7.7 & $44.4 \%$ & $6.1 \%$ & 3,779 & $2.60 \%$ & $32.6 \%$ & $8.0 \%$ & $2.86 \%$ \\
\hline & 6.5 & $42.5 \%$ & $6.7 \%$ & 547 & $0.38 \%$ & $36.9 \%$ & $2.9 \%$ & $0.58 \%$ \\
\hline Samarskaya Oblast' & 3.4 & $48.3 \%$ & $5.0 \%$ & 3,240 & $2.23 \%$ & $39.0 \%$ & $5.9 \%$ & $2.46 \%$ \\
\hline \multirow{2}{*}{$\begin{array}{l}\text { Tomskaya Oblast' } \\
\text { Tyumenskaya Oblast' }\end{array}$} & 10.7 & $43.1 \%$ & $6.5 \%$ & 1,046 & $0.72 \%$ & $41.7 \%$ & $4.8 \%$ & $0.88 \%$ \\
\hline & 81.8 & $50.1 \%$ & $4.5 \%$ & 1,325 & $0.91 \%$ & $27.2 \%$ & $0.9 \%$ & $1.09 \%$ \\
\hline \multirow{2}{*}{$\begin{array}{l}\text { Udmurtskaya Resp. } \\
\text { Volgogradskaya } \\
\text { Oblast' }\end{array}$} & 5.5 & $38.9 \%$ & $8.0 \%$ & 1,570 & $1.08 \%$ & $35.0 \%$ & $8.6 \%$ & $0.84 \%$ \\
\hline & 1.3 & $41.2 \%$ & $7.1 \%$ & 2,699 & $1.86 \%$ & $38.9 \%$ & $14.2 \%$ & $1.15 \%$ \\
\hline Yamalo-Nenetskii AO & 85.7 & $47.7 \%$ & $5.2 \%$ & 507 & $0.35 \%$ & $23.7 \%$ & $0.1 \%$ & $2.70 \%$ \\
\hline
\end{tabular}

Notes: Tomskaya Oblast' refers to the area excluding the autonomous regions, apart from the data of shares of agriculture and services, which relate to all its territory. On the 1 December 2005, Permskaya Oblast' was merged with Komi-Permyak Autonomous Okrug into Permskii Krai. The data refer to the period before the merger.

Source: Goskomstat Rosii. 
TABLE 2. DETERMINANTS OF PERCENTAGE SHARES OF INCOME ACROSS POPULATION QUINTILES FOR 86 RUSSIAN REGIONS OVER 2000-2004.

\begin{tabular}{|c|c|c|c|c|c|}
\hline \multicolumn{6}{|c|}{-System GMM- } \\
\hline \multirow{3}{*}{ L. dep_var } & FIRST & SECOND & THIRD & FOURTH & FIFTH \\
\hline & 0.742 & 0.721 & 0.781 & 0.873 & 0.851 \\
\hline & $(0.088)^{* * *}$ & $(0.097)^{* * *}$ & $(0.098)^{* * *}$ & $(0.089)^{* * *}$ & $(0.087)^{* * *}$ \\
\hline \multirow[t]{2}{*}{ P_OIL\&GAS } & -0.004 & -0.005 & -0.003 & -0.001 & 0.008 \\
\hline & $(0.002)^{* *}$ & $(0.002)^{* *}$ & $(0.002)$ & $(0.001)^{*}$ & $(0.006)$ \\
\hline \multirow[t]{2}{*}{ ENROLMENT_RATE } & -0.002 & -0.002 & -0.003 & -0.001 & 0.008 \\
\hline & $(0.004)$ & $(0.004)$ & $(0.003)$ & $(0.001)$ & $(0.01)$ \\
\hline \multirow[t]{2}{*}{ 1_RGDP } & -0.08 & -0.093 & -0.058 & -0.015 & 0.155 \\
\hline & $(0.056)$ & $(0.061)$ & $(0.044)$ & $(0.013)$ & $(0.157)$ \\
\hline \multirow[t]{2}{*}{ 1_EXPORT } & 0.009 & 0.022 & 0.002 & 0.008 & 0.017 \\
\hline & $(0.035)$ & $(0.037)$ & $(0.027)$ & $(0.007)$ & $(0.107)$ \\
\hline \multirow[t]{2}{*}{ SERV } & -0.007 & -0.006 & -0.003 & -0.001 & 0.013 \\
\hline & $(0.003)^{* *}$ & $(0.003)^{*}$ & $(0.002)$ & $(0.001)$ & $(0.01)$ \\
\hline \multirow[t]{2}{*}{$\mathrm{YEAR}==2001$} & 0.044 & 0.066 & 0.014 & 0.017 & 0.032 \\
\hline & $(0.061)$ & $(0.069)$ & $(0.046)$ & $(0.009)^{*}$ & $(0.191)$ \\
\hline \multirow[t]{2}{*}{$\mathrm{YEAR}==2002$} & -0.049 & -0.037 & -0.046 & -0.004 & 0.285 \\
\hline & $(0.053)$ & $(0.06)$ & $(0.042)$ & $(0.01)$ & $(0.143)^{* *}$ \\
\hline \multirow[t]{2}{*}{$\mathrm{YEAR}==2003$} & -0.196 & -0.181 & -0.162 & -0.024 & 0.656 \\
\hline & $(0.036)^{* * *}$ & $(0.041)^{* * *}$ & $(0.032) * * *$ & $(0.010)^{* *}$ & $(0.128)^{* * *}$ \\
\hline \multirow[t]{2}{*}{ Constant } & 2.874 & 4.393 & 4.44 & 3.077 & 3.776 \\
\hline & $(0.854)^{* * *}$ & $(1.368)^{* * *}$ & $(1.797)^{* *}$ & -2.07 & -3.863 \\
\hline Observations & 337 & 337 & 337 & 337 & 337 \\
\hline Number of ID & 86 & 86 & 86 & 86 & 86 \\
\hline Number of instruments & 86 & 86 & 86 & 86 & 86 \\
\hline \multicolumn{6}{|c|}{ Arellano-Bond test for $\mathrm{AR}(1)$ in first differences: } \\
\hline$z=$ & -2.93 & -2.91 & -3.23 & -3.70 & -3.08 \\
\hline \multirow[t]{2}{*}{$\operatorname{Pr}>z=$} & 0.003 & 0.004 & 0.001 & 0.000 & 0.002 \\
\hline & \multicolumn{5}{|c|}{ Arellano-Bond test for $\mathrm{AR}(2)$ in first differences: } \\
\hline $\mathrm{z}=$ & -0.75 & -0.31 & -0.34 & -0.41 & -0.72 \\
\hline \multirow[t]{2}{*}{$\operatorname{Pr}>z=$} & 0.452 & 0.753 & 0.737 & 0.682 & 0.473 \\
\hline & \multicolumn{4}{|c|}{ Hansen test of over-identifying restrictions: } & \\
\hline $\operatorname{chi} 2(22)$ & 36.28 & 36.88 & 34.83 & 47.88 & 38.20 \\
\hline Prob $>$ chi 2 & 0.455 & 0.428 & 0.524 & 0.089 & 0.370 \\
\hline $\begin{array}{r}\text { Robust stand } \\
* \text { signifi }\end{array}$ & $\begin{array}{l}\text { ors in parentl } \\
10 \% ; * * \text { sigr }\end{array}$ & $t$ at $5 \% ; * * *$ & ficant at $1 \%$ & & \\
\hline
\end{tabular}


TABLE 3. DETERMINANTS OF THE GAP IN SHARES OF INCOME ACROSS POPULATION QUINTILES. ALL DIFFERENCES ARE COMPUTED WITH RESPECT TO THE RICHEST PERCENTILE FOR 86 RUSSIAN REGIONS FOR 2000-2004.

\section{-System_GMM-}

\begin{tabular}{|c|c|c|c|c|}
\hline L.dep_var & $\begin{array}{c}\text { DIST_FIRST_FIFTH } \\
0.533 \\
(0.126)^{* * *}\end{array}$ & $\begin{array}{c}\text { DIST_SECOND_FIFTH } \\
0.537 \\
(0.126)^{* * *}\end{array}$ & $\begin{array}{c}\text { DIST_THIRD_FIFTH } \\
0.551 \\
(0.126)^{* * *}\end{array}$ & $\begin{array}{c}\text { DIST_FOURTH_FIFTH } \\
0.574 \\
(0.123)^{* * *}\end{array}$ \\
\hline P_OIL\&GAS & $\begin{array}{c}0.03 \\
(0.012)^{* * *}\end{array}$ & $\begin{array}{c}0.031 \\
(0.012)^{* * *}\end{array}$ & $\begin{array}{c}0.028 \\
(0.011)^{* *}\end{array}$ & $\begin{array}{c}0.023 \\
(0.009)^{* *}\end{array}$ \\
\hline 1_RGDP & $\begin{array}{c}0.274 \\
(0.222)\end{array}$ & $\begin{array}{c}0.311 \\
(0.224)\end{array}$ & $\begin{array}{c}0.311 \\
(0.217)\end{array}$ & $\begin{array}{c}0.28 \\
(0.184)\end{array}$ \\
\hline ENROLMENT_RATE & $\begin{array}{c}0.011 \\
(0.013)\end{array}$ & $\begin{array}{c}0.011 \\
(0.014)\end{array}$ & $\begin{array}{c}0.013 \\
(0.012)\end{array}$ & $\begin{array}{l}0.012 \\
(0.01)\end{array}$ \\
\hline 1_EXPORT & $\begin{array}{l}-0.044 \\
(0.11)\end{array}$ & $\begin{array}{l}-0.051 \\
(0.112)\end{array}$ & $\begin{array}{l}-0.047 \\
(0.106)\end{array}$ & $\begin{array}{l}-0.043 \\
(0.089)\end{array}$ \\
\hline SERV & $\begin{array}{c}0.028 \\
(0.019)\end{array}$ & $\begin{array}{c}0.028 \\
(0.019)\end{array}$ & $\begin{array}{c}0.024 \\
(0.017)\end{array}$ & $\begin{array}{c}0.019 \\
(0.014)\end{array}$ \\
\hline $\mathrm{YEAR}==2001$ & $\begin{array}{c}-0.834 \\
(0.421)^{* *}\end{array}$ & $\begin{array}{c}-0.811 \\
(0.418)^{*}\end{array}$ & $\begin{array}{c}-0.7 \\
(0.385)^{*}\end{array}$ & $\begin{array}{c}-0.534 \\
(0.305)^{*}\end{array}$ \\
\hline $\mathrm{YEAR}==2002$ & $\begin{array}{c}-0.298 \\
(0.342)\end{array}$ & $\begin{array}{l}-0.275 \\
(0.34)\end{array}$ & $\begin{array}{l}-0.229 \\
(0.317)\end{array}$ & $\begin{array}{c}-0.146 \\
(0.256)\end{array}$ \\
\hline $\mathrm{YEAR}==2003$ & $\begin{array}{c}0.445 \\
(0.207)^{* *}\end{array}$ & $\begin{array}{c}0.453 \\
(0.207)^{* *}\end{array}$ & $\begin{array}{c}0.454 \\
(0.195)^{* *}\end{array}$ & $\begin{array}{c}0.396 \\
(0.159)^{* *}\end{array}$ \\
\hline Constant & $\begin{array}{c}12.619 \\
(5.505)^{* *}\end{array}$ & $\begin{array}{c}9.889 \\
(4.887)^{* *}\end{array}$ & $\begin{array}{c}7.319 \\
(4.236)^{*}\end{array}$ & $\begin{array}{c}4.305 \\
-3.184\end{array}$ \\
\hline Observations & 330 & 330 & 330 & 330 \\
\hline Number of ID & 86 & 86 & 86 & 86 \\
\hline Number of instruments & 86 & 86 & 86 & 86 \\
\hline \multicolumn{5}{|c|}{ Arellano-Bond test for $\mathbf{A R}(1)$ in first differences: } \\
\hline$z=$ & -2.35 & -2.41 & -2.45 & -2.56 \\
\hline $\operatorname{Pr}>\mathrm{z}=$ & 0.019 & 0.016 & 0.014 & 0.010 \\
\hline \multicolumn{5}{|c|}{ Arellano-Bond test for $\mathrm{AR}(2)$ in first differences: } \\
\hline$z=$ & -0.24 & -0.18 & -0.18 & -0.22 \\
\hline $\operatorname{Pr}>z=$ & 0.813 & 0.855 & 0.856 & 0.822 \\
\hline \multicolumn{5}{|c|}{ Hansen test of over-identifying restrictions: } \\
\hline $\operatorname{chi} 2(22)$ & 58.92 & 60.29 & 59.23 & 59.91 \\
\hline Prob $>$ chi 2 & 0.268 & 0.229 & 0.259 & 0.239 \\
\hline
\end{tabular}

Robust standard errors in parentheses: * significant at 10\%; ** significant at 5\%; *** significant at $1 \%$ 
TABLE 4. TESTING DIFFERENT DEPENDENT VARIABLES ON THE MODEL. THE TIME SPAN IS 2003-2005 FOR THE GINI INDEX AND FOR THE RATIO BETWEEN THE INCOME PERCEIVED BY THE RICHEST $10 \%$ AND THE POOREST $10 \%$ (DIFF_INCOME). FOR THE THEIL IT IS INSTEAD 2000-2004.

-Between Effects-

\begin{tabular}{|cccc|}
\hline & \multicolumn{2}{c|}{-Between Effects- } & \\
\hline \hline & & & THEIL \\
PINI & Coef_Diff_Income & 0.053 \\
P_OIL\&GAS & 0.001 & 0.063 & $(0.006)^{* * *}$ \\
1_RGDP & $(0.0001)^{* * *}$ & $(0.008)^{* * *}$ & 0.298 \\
& 0.011 & 0.928 & $(0.188)$ \\
ENROLMENT_RATE & $(0.004)^{* * *}$ & $(0.279)^{* * *}$ & -0.009 \\
& 0.000 & 0.01 & $(0.01)$ \\
1_EXPORT & $(0.000)$ & $(0.016)$ & 0.004 \\
& -0.003 & -0.232 & $(0.108)$ \\
SERV & $(0.002)$ & $(0.163)$ & 0.01 \\
& 0.001 & 0.051 & $(0.012)$ \\
Constant & $(0.000)^{* * *}$ & $(0.018)^{* * *}$ & -3.265 \\
& 0.216 & -1.201 & $(1.869)^{*}$ \\
Observations & $(0.036)^{* * *}$ & $(2.878)$ & 411 \\
Number of ID & 255 & 255 & 86 \\
R-squared & 86 & 86 & 0.75 \\
Standard errors in parentheses* significant at $10 \% ; *$ significant at $5 \% ; * * *$ significant at $1 \%$
\end{tabular}


FIGURE 1. REGIONS OF RUSSIA WITH LARGE PRODUCTION OF OIL AND GAS PER HEAD

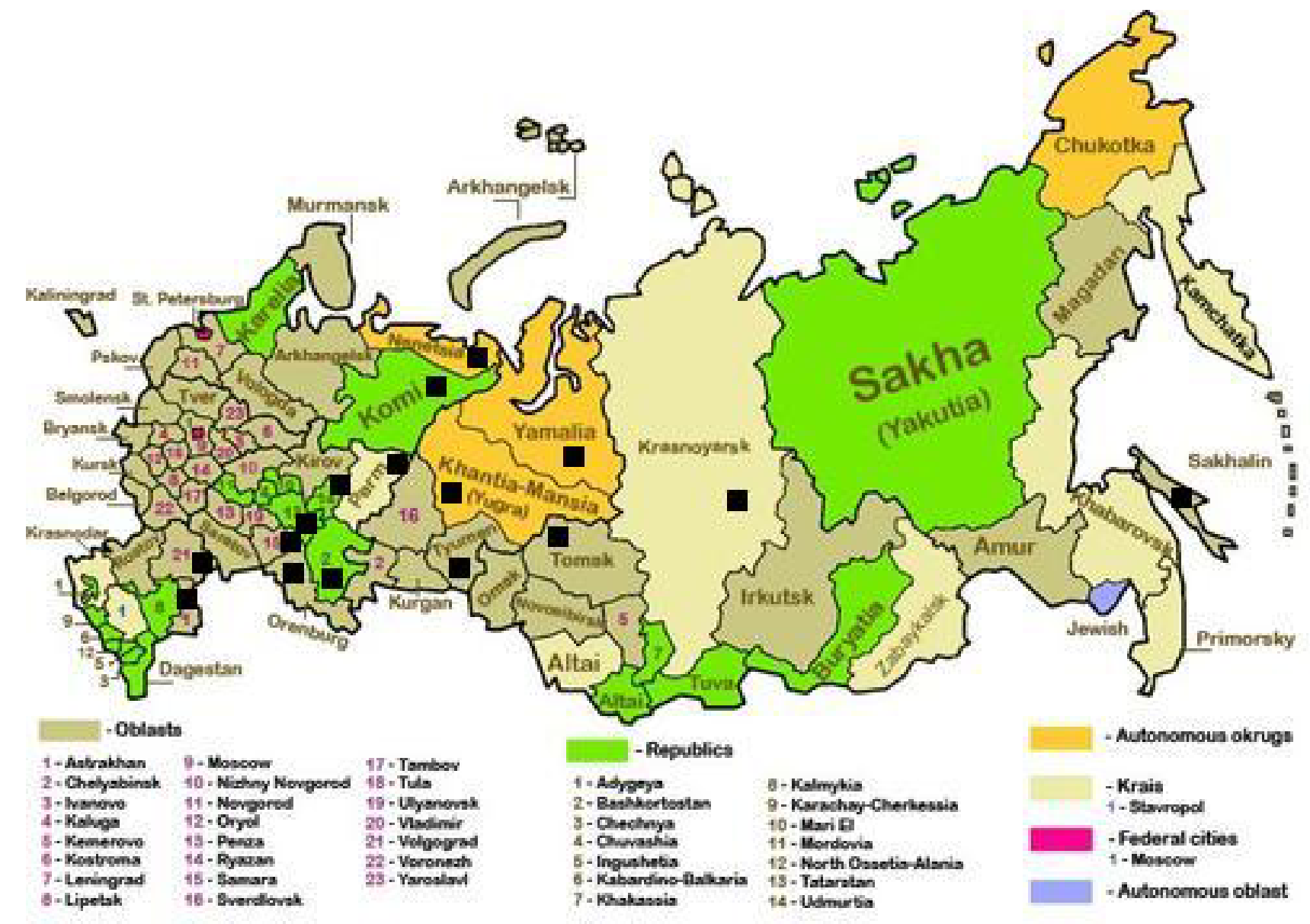




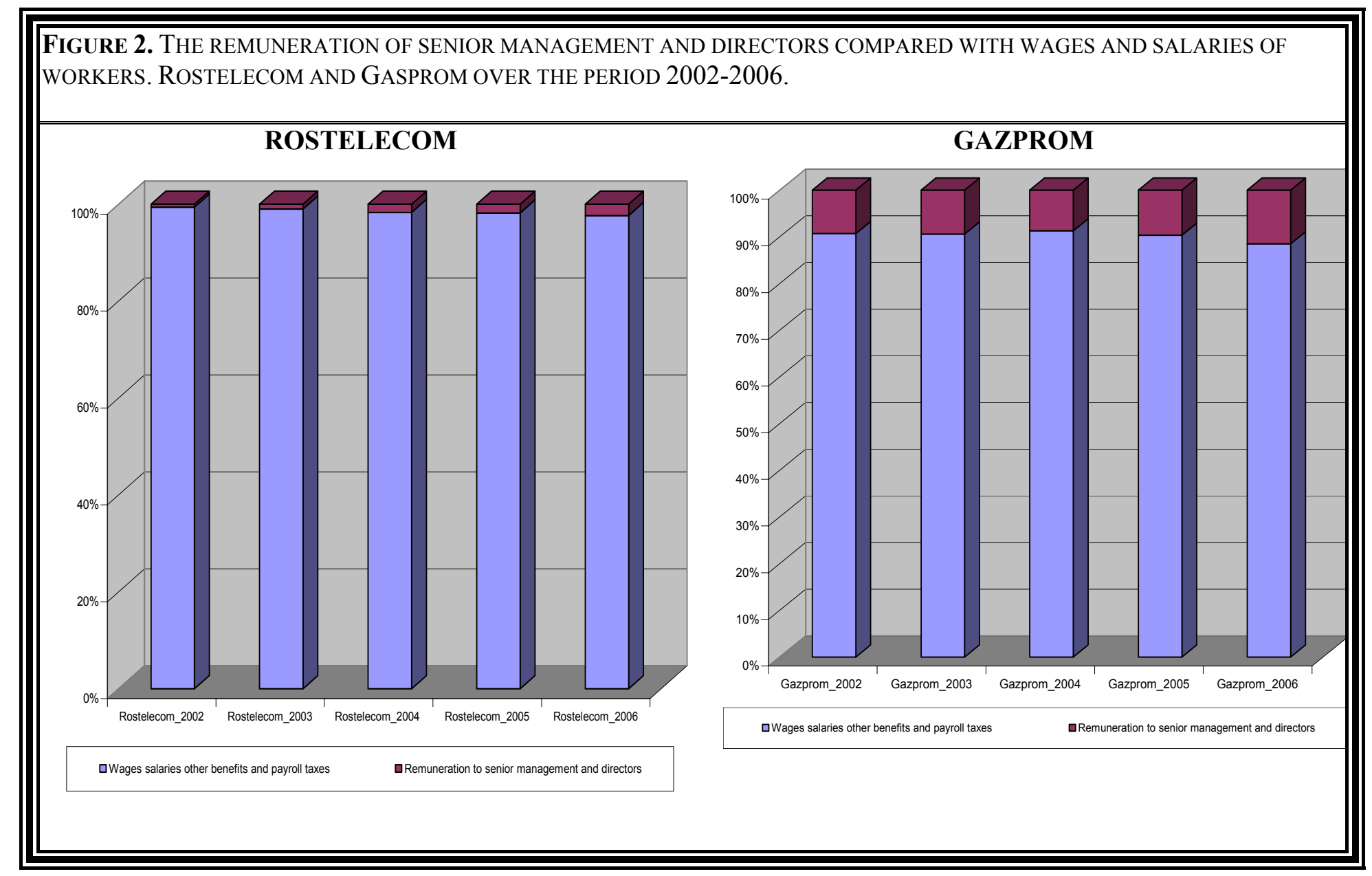

Source: Financial Reports of the two companies for the period considered (2002-2006) 
FiguRE 3. PER CAPITA AVERAGE MONTHLY TRANSFERS IN RUBLES AND PERCENTAGE OF PEOPLE LIVING BELOW THE POVERTY THRESHOLD IN 87 RUSSIAN REGIONS IN 2005.

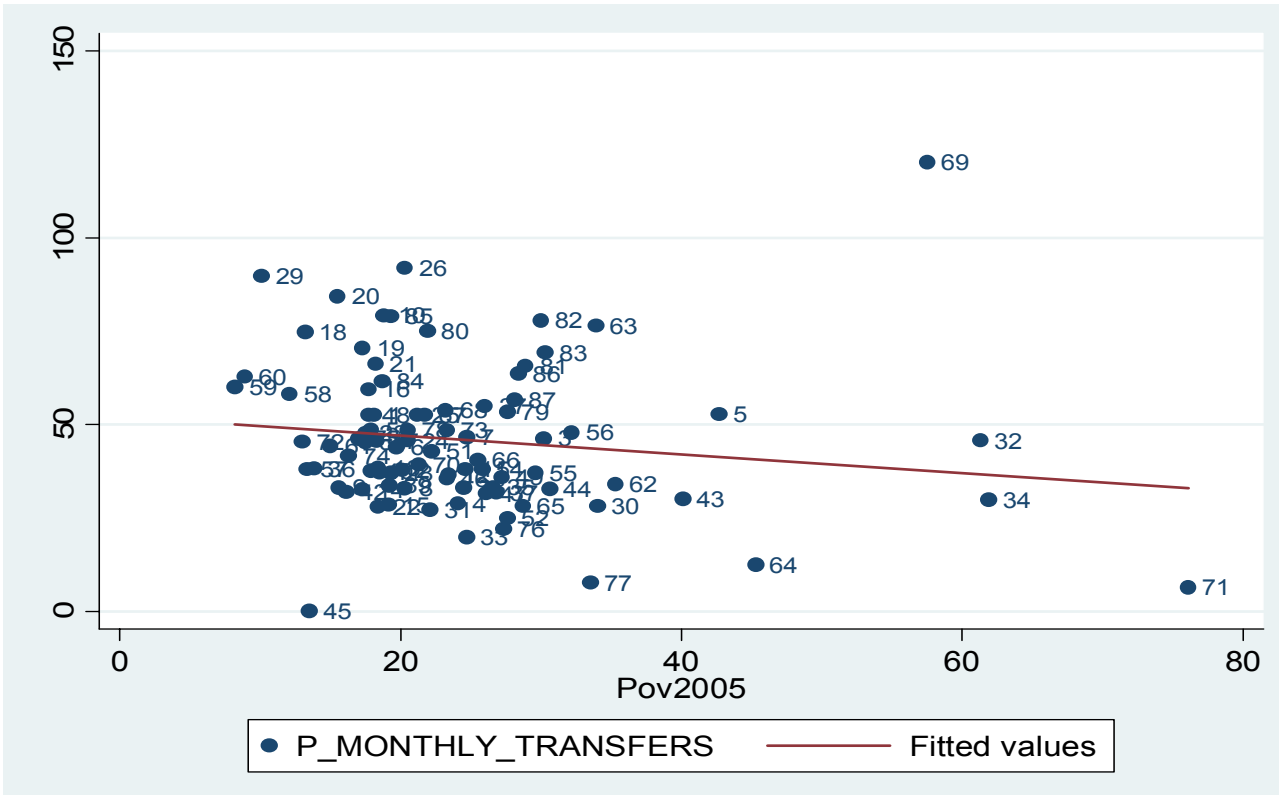

\section{REGION}

Belgorodskaya Oblast' Bryanskaya Oblast'

Vladimirskaya Oblast'

Voronezhskaya Oblast'

Ivanovskaya Oblast'

Kaluzhskaya Oblast'

Kostromskaya Oblast'

Kurskaya Oblast'

Lipetskaya Oblast'

Moskovskaya Oblast'

Orlovskaya Oblast'

Ryazanskaya Oblast'

Smolenskaya Oblast'

Tambovskaya Oblast'

Tverskaya Oblast'

Tulskaya Oblast'

Yaroslavskaya Oblast

G. Moskva

Respublika Karelia

Respublika Komi

Arkhangelskaya Oblast'

Nenetskii AO

Vologodskaya Oblast'

Kaliningradskaya Oblast'

Leningradskaya Oblast'

Murmanskaya Oblast'

Novgorodskaya Oblast'

Pskovskaya Oblast'

G. Sankt-Peterburg

\section{ID REGION}

1 Respublika Adygeya

2 Respublika Dagestan

3 Respublika Ingushetia

4 Kabardino-Balkarskaya Respublika

5 Respublika Kalmykia

6 Karachaevo-Cherkesskaya Respublika

7 Respublika Severnaya Osetiya-Alaniya

8 Krasnodarskii krai

9 Stavropolskii krai

10 Astrakhanskaya Oblast'

11 Volgogradskaya Oblast'

12 Rostovskaya Oblast'

13 Respublika Bashkortostan

14 Respublika Mari El

15 Respublika Mordovia

16 Respublika Tatarstan

17 Udmurtskaya Respublika

18 Chuvashskaya Respublika

19 Kirovskaya Oblast'

20 Nizhegorodskaya Oblast'

21 Orenburgskaya Oblast'

22 Penzenskaya Oblast'

23 Permskaya Oblast'

24 Samarskaya Oblast'

25 Saratovskaya Oblast'

26 Ulyanovskaya Oblast'

27 Kurganskaya Oblast'

28 Sverdlovskaya Oblast'

29 Tyumenskaya Oblast'

\section{REGION}

Khanty-Mansiiskii AO

Yamalo-Nenetskii AO

Chelyabinskaya Oblast'

Respublika Altai

Respublika Buryatiya

Respublika Tyva

Respublika Khakasya

Altayskii krai

Krasnoyarskii krai

Taimyrskii AO

Evenkiiskii AO

Irkutskaya oblast ${ }^{\text {' }}$

Ust-Ordynskii Buryatskii AO

Kemerovskaya Oblast'

Novosibirskaya Oblast'

Omskaya Oblast'

Tomskaya Oblast'

Chitinskaya Oblast'

Aginskii Buryatskii AO

Respublika Sakha (Yakutiya)

Primorskii krai

Khabarovskii krai

Amurskaya Oblast'

Kamchatskaya oblast'

Koryakskii AO

Magadanskaya Oblast'

Sakhalinskaya Oblast ${ }^{\prime}$

Evreiskaya avtomnaya oblast ${ }^{\prime}$

Chukotskii Avtonom. Okrug

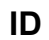

59 
FIGURE 4: THEIL'S T STATISTIC COMPUTED FOR 87 RUSSIAN REGIONS OVER THE PERIOD 1995, 20002004.

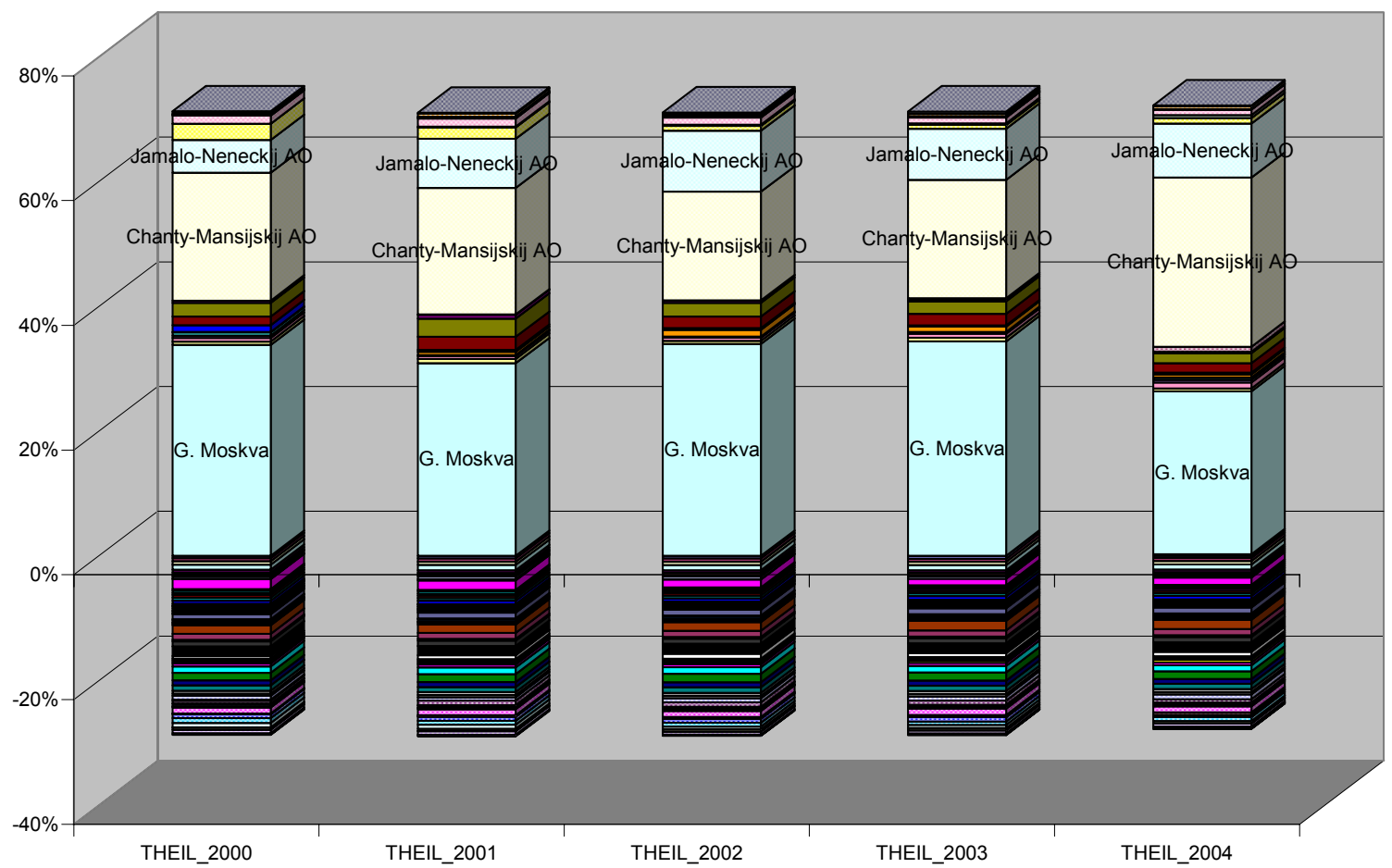

